\title{
Self-Sacrifice and the Other(s): Reflections on Andrei Tarkovksy's The Sacrifice
}

\author{
Frederiek Depoortere
}

\section{1 \\ Introduction}

In 1986, the year of his death from cancer at the age of 54 , the expatriate Russian filmmaker Andrei Tarkovsky published his last film, titled The Sacrifice. It presents the character of Alexander, a former actor who has now become an essayist and lecturer. The film takes place on his fiftieth birthday, a day celebrated with his family and a few friends in his mansion in a remote corner of the Swedish countryside. This party is interrupted when the television news announces that a nuclear war has broken out. In his desperation Alexander turns to God, in whom he had not believed until then. He promises God to sacrifice all he possesses and to remain mute for the rest of his life, if only God will save his family and friends from the imminent nuclear holocaust. When he wakes up the next morning, everything has gone back to normal, as if nothing had happened the previous day. Alexander then fulfils his part of the deal: He burns down his house, and is taken in an ambulance to be locked up in a psychiatric hospital, unable to explain his deed because of his vow of silence. ${ }^{1}$

2

\section{A Multi-Layered Plot}

Tarkovsky's last film has confronted its viewers and interpreters with many puzzles and unresolved questions. As pointed out by the Australian cinematographer Gino Moliterno, many critics, even those who think favorably of Tarkovsky, have claimed that the film is "flawed" and "strongly undermined by considerable narrative and thematic confusion". ${ }^{2}$ Part of this confusion is

1 Andrei Tarkovsky, Collected Screenplays, trans. William Powell and Natasha Synessios (London: Faber and Faber, 1999), 505-56o; Andrei Tarkovsky, The Sacrifice [film]; with Erland Josephson, Susan Fleetwood, Allan Edwall. For further details on the film, see http://www .imdb.com/title/ttoog1670/. In what follows, I refer to the 142 minutes version of the film as distributed by Moskwood Media, Haarlem, The Netherlands.

2 Gino Moliterno, "Zarathustra's Gift in Tarkovsky's The Sacrifice," Screening the Past: An International, Refereed, Electronic Journal of Screen History 12 (2001), http://www.latrobe.edu .au/screeningthepast/firstrelease/frozor/gmfriza.htm.

(C) FREDERIEK DEPOORTERE, 2017 | DOI 10.1163/9789004335530_005

This is an open access chapter distributed under the terms of the CC BY-NCY 4 0 license 
caused by the fact that in the film we actually get two crises at the same time. There is - just as in the narrative of the African sacrifice ${ }^{3}$ - a close connection between sacrifice and the fate of the community. As outlined by Mark Le Fanu in his discussion of the film, next to the political crisis on a planetary scale (the imminent nuclear holocaust), there is also a personal crisis: A marriage crisis between Alexander and his wife Adelaida, who is suggested to have an affair with their friend Victor. The significance of this affair for his sacrifice is never completely fleshed out. ${ }^{4}$ On top of this, things become even more complex when Alexander, after he has made his vow to God, is visited in the middle of the night by Otto, the postman and a friend who was also present at his birthday party. Otto urges him to go to the house of his servant Maria and to sleep with her. She is a witch of the best kind, Otto knows, and spending the night with her will return things to normal. Alexander first objects, but eventually yields and goes off to Maria's. This narrative complication is a remainder of the first drafts of the manuscript of the film, which was originally titled The Witch and would tell the story of a man who is cured of a fatal disease after sleeping with a witch. ${ }^{5}$ The imminent nuclear holocaust and the pact with God were only added at a later stage. The relation between Alexander's pact with God and Otto's promise of redemption through Maria remains unclear, however. Or, as Peter Green puts it: "Is this [promise] an immediate answer to [Alexander's] prayers, the response to his vow, or is it an alternative to sacrifice?". ${ }^{6}$ In the end it is, as Le Fanu notes, unclear what returned things to normal: The deal with God, the night spent with Maria, or neither: Maybe the superpowers returned to their senses and the nuclear war was stopped anyway, independently of any act of Alexander. ${ }^{7}$

\section{3} Three Philosophical Issues

Tarkovsky's The Sacrifice also raises several questions of a philosophical nature. A first question concerns the characterization of the sacrificial gesture in The Sacrifice. During an interview in March 1986, Tarkovsky stated that

3 See the contribution of W. E. A. van Beek in this volume.

4 Mark Le Fanu, The Cinema of Andrei Tarkovsky (repr., London: British Film Institute, 1990), 125 .

5 Andrey Tarkovsky, Sculpting in Time: Reflections on the Cinema, trans. Kitty Hunter-Blair (Austin, University of Texas Press 1989), 219-220.

6 Peter Green, “Apocalypse and Sacrifice," Sight and Sound 56, 2 (1987), 111-118 (118).

7 Le Fanu, The Cinema of Andrei Tarkovsky, 126-127. 
The Sacrifice is a film on self-sacrifice. ${ }^{8}$ He made similar claims in Sculpting in Time, the book in which the filmmaker discussed his work. ${ }^{9}$ Yet, is it correct to designate Alexander's sacrificial gesture as a self-sacrifice? Alexander indeed offers a number of things that matter a lot to him (such as his house and the contact with his young son, nicknamed "Little Man"), but he does not seem to be offering himself.

Another problem raised by Tarkovsky's depiction of Alexander's sacrificial gesture is the way the latter's family is involved in it. Several critics have formulated their unease in this regard. Moliterno, for instance, has put this as follows: "How can burning the home of his loved ones, the ones for whom he makes the pact with God, be an appropriate self-sacrifice for Alexander?"10 In this regard, Moliterno quotes Philip Strick, who in a 1987 review of The Sacrifice wondered why Alexander would deprive his family of their possessions (by burning down their house) in his attempt to offer atonement. ${ }^{11} \mathrm{~A}$ similar observation has been made by Le Fanu, who asks whether "sacrifice [can] be sacrifice if it implicates innocent people". ${ }^{2}$ The example of Alexander suggests that others are always involved in any act of sacrifice and raises the question of the role played by sacrifice in the relationship of an individual with these others.

A further question that is raised by The Sacrifice, as pointed out by Le Fanu, is to what extent we should take Alexander as an exemplar. ${ }^{13}$ Is a sacrificial gesture like Alexander's advisable, and is it desirable? Should we all try to do like him? There are reasons to accept that Tarkovsky intended the hero of his last film to function as a moral exemplar. In the aforementioned interview from 1986, he explained that as far as he is concerned, self-sacrifice is what makes a human being truly human and distinguishes him or her from the animals. Somebody who does not possess the desire for self-sacrifice, in Tarkovsky's view, has "ceased to be a man" and "begins to revert to the animal condition and becomes a strange machine, an object to be experimented with by society and the state.". ${ }^{14}$ But was Tarkovsky correct in defending the moral desirability of self-sacrifice?

Annie Epelboin, "Andrei Tarkovsky on The Sacrifice," interview, see http://people.ucalgary .ca/ tstronds/nostalghia.com/TheTopics/On_Sacrifice.html. Tarkovsky, Sculpting in Time, 218.

10 Moliterno, "Zarathustra's Gift."

11 See Philip Strick, "Offret (The Sacrifice)," Monthly Film Bulletin 636 (January 1987), 7-8 (7).

12 Le Fanu, The Cinema of Andrei Tarkovsky, 125.

13 Le Fanu, The Cinema of Andrei Tarkovsky, 124.

14 Epelboin, "Andrei Tarkovsky on The Sacrifice." 
In what follows, I will take up the three philosophical issues that arise from The Sacrifice (the character of self-sacrifice, the role played by self-sacrifice in the relationship with one's others, and the desirability of self-sacrifice), seeking to clarify the philosophy of sacrifice that is present in Tarkovsky's final film.

\section{Is the Sacrifice of "The Sacrifice" a Self-Sacrifice?}

Let us begin with the question whether Alexander's sacrificial gesture can rightly be considered a self-sacrifice. To answer this question, we of course need to know what a self-sacrifice, or sacrifice of the self, is. This immediately raises two further questions: What is sacrifice? And what is "the self" that is sacrificed in an act of self-sacrifice? The Cambridge Advanced Learner's Dictionary distinguishes between two meanings of the verb "to sacrifice". The dictionary's first meaning of to sacrifice is "to give up something that is valuable to you, in order to help another person",15 the second is "to kill an animal or a person and offer them to a god or gods". ${ }^{16}$ These definitions clearly show that sacrifice, be it secular or religious, involves someone else: Be it the god(s) to whom the sacrifice is addressed or the person or people for whose benefit one sacrifices. This suggests that in a sacrificial gesture four elements can be distinguished: The sacrificing subject (A), the sacrificed object (B), the addressee of the sacrifice $(C)$, and the reason for the sacrifice $(D)$. We might design the formal structure of a sacrifice as: "A sacrificing B to $\mathrm{C}$ for the sake of D".17

This leads us back to the concept of self-sacrifice. The main problem with it is the meaning of 'self' in the word 'self-sacrifice'. An evident way to understand the 'self' in 'self-sacrifice' is as pointing to self-sacrifice as reflexive sacrifice, a sacrifice in which the subject sacrificing $(A)$ and the object sacrificed (B) are identical $(B=A)$. This is the way Claudia Welz understands selfsacrifice. In her view, self-sacrifice has the following formal structure: "A sacrificing $\mathrm{A}$ to $\mathrm{C}$ for the sake of $\mathrm{D}$ ". ${ }^{18}$ Regarding the required identity of the subject sacrificing and the object sacrificed, Welz writes the following:

\footnotetext{
15 http://dictionary.cambridge.org/dictionary/british/sacrifice_1. The addition of 'that is valuable to you' is important: the term sacrifice is only used appropriately when it refers to a giving-up which is costly and painful.

16 http://dictionary.cambridge.org/dictionary/british/sacrifice_2.

17 I have adopted this formal structure of sacrifice from Claudia Welz, "Love as Gift and SelfSacrifice," Neue Zeitschrift für Systematische Theologie und Religionsphilosophie 50, 3-4 (2008), 238-66 (at 246).

18 Welz, "Love as Gift and Self-Sacrifice," 246.
} 
If the sacrificed self is not exactly the same as the sacrificing self, the self-sacrifice is incomplete. It is only a feature of the self or an aspect of its self-image that might be sacrificed. The self sacrificing itself survives the sacrifice of itself, ready for repeated self-sacrifices. ${ }^{19}$

Thus, according to Welz, a sacrifice can only be considered a self-sacrifice in cases where somebody dies for somebody else, when the sacrificing self does not survive the sacrifice. ${ }^{20}$ If we adopt this view, Alexander's sacrifice as it is depicted in Tarkovsky's film is clearly not a self-sacrifice: He does not give his life. If we put Alexander's sacrificial gesture in a formula, we get the following: Alexander (A) sacrificing his house and the contact with his son (B) to God (C) for the well-being of his family and friends (D). The sacrificing subject (Alexander) and the object sacrificed (his house and the contact with his son) are clearly not identical, in contrast to what one would expect if one follows Welz in defining self-sacrifice as a sacrifice in which B $=\mathrm{A}$. Does this show that Tarkovsky was wrong in designating the sacrifice in his last film as a self-sacrifice? Or does Alexander's example suggest that we can understand self-sacrifice in another way?

\subsection{Moliterno's Nietzschean Interpretation}

To help us answer these questions, I now turn to Gino Moliterno's interpretation of Tarkovsky's film. Moliterno proposes a Nietzschean reading of Alexander's gesture to burn down his house. This interpretation is accounted for by a reference to Nietzsche during a conversation between Alexander and his friend Otto in the first scene of The Sacrifice. Otto reprimands Alexander for always being gloomy and depressed. He suspects that Alexander is like most people, who are waiting their entire life for "something real and important" to happen, but who meanwhile forget to live life here and now. Otto admits that he is no different in this regard: He, too, is waiting, but he adds that he is often haunted by that notorious hunchbacked dwarf from Nietzsche, "the one that sent Zarathustra into a fainting fit". ${ }^{21}$ This is a reference to the second section of the third part of Nietzsche's Thus Spoke Zarathustra. In this section, which is titled "On the Vision and the Riddle", Zarathustra tells about his encounter with "the spirit of gravity", his "devil and arch-enemy", who is sitting on his

19 Ibidem.

20 Welz, "Love as Gift and Self-Sacrifice," 246-47.

21 Tarkovsky, Collected Screenplays, 518-19; Tarkovsky, The Sacrifice [film], og:25-11:15 (i.e. a fragment starting at 9 minutes and 25 seconds and ending at 11 minutes and 15 seconds in the film). 
shoulders and is pushing him down, while he wants to go upwards. This devil is subsequently depicted as "half dwarf, half mole, lame, paralyzing, dripping lead into my ear, lead-drop thoughts in my brain". ${ }^{22}$ This hunchbacked dwarf is thus a symbol for everything that sickens the human spirit and pulls it down. Or, as Moliterno puts it:

[T] he dwarf is a personification of nihilism, [which is the] failure to value the present moment in its eternal 'nowness', thus manifesting a dissatisfaction with, and ultimately a hatred of, the world, life and oneself. For Nietzsche, nihilism is an existential ailment or nausea, a sickness typified by a yearning for a different, better world or condition but a yearning which, in its 'otherworldliness', inevitably deprecates and de-values this earth and this life. ${ }^{23}$

Given this characterization of nihilism, Moliterno concludes that Alexander clearly passes the test as a nihilist. This can be derived from the second scene of the film, immediately following the conversation between Alexander and Otto. In this scene, we get a long monologue by Alexander in which he complains about the deplorable state of humankind. Since sin is everything that is not necessary, he views human civilization as mostly, if not completely, sinful. ${ }^{24}$ However, he is aware of the fact that he is no better than the rest. Towards the end of the scene, Alexander gets annoyed with his own idle chatter and expresses a desire for action, something of which he is not capable himself. ${ }^{25}$ Alexander is clearly infected by the spirit of gravity, which depresses and paralyzes him. His desire for another, better world makes him melancholy, gloomy, and weary. He wallows in self-pity and pessimism. He is a prototypical nihilist.

This leads Moliterno to his Nietzschean interpretation of Alexander's sacrifice, which should, in his view, be understood as "a joyful act of affirmative self-transfiguration". ${ }^{26}$ In this respect, it is highly significant that Alexander's

22 Friedrich Nietzsche, Thus Spoke Zarathustra: A Bookfor All and None, eds Adrian Del Caro and Robert B. Pippin, trans. Adrian Del Caro (Cambridge: Cambridge University Press, 2006), 124 .

23 Moliterno, "Zarathustra's Gift." In this regard, Moliterno refers to Bernd Magnus, Nietzsche's Existential Imperative: Studies in Phenomenology and Existential Philosophy (Bloomington: Indiana University Press, 1978), 42 and 144-145, where nihilism is interpreted as being caused by "systematic dualism," that is, a "contempt for the earth and the earthly," the yearning for "a different, a better world or condition."

24 Tarkovsky, Collected Screenplays, 523; The Sacrifice [film], 19:38.

25 Tarkovsky, The Sacrifice [film], 20:23-20:51.

26 Moliterno, "Zarathustra's Gift." 
sacrificial gesture consists in burning down his house. The house is not only, as pointed out by Moliterno, "a fairly transparent symbol of the self", ${ }^{27}$ it also stands for one's past. At home, the past can live on. It is a place where memories are kept alive, where souvenirs and other objects constantly serve as reminders of past events and people one once knew. As such, one's house can become a place in which one can hide from the real life out there. This is precisely the role the house plays in The Sacrifice. It is no coincidence that it is situated in a remote corner of the Swedish countryside, since its owner is a man who has given up his busy life as an actor in London, has turned his back on the world and is now leading a secluded life of nostalgia and world-weariness. By burning down his own house, Alexander is breaking free from the burden of the past, from his "domiciled worldweariness", from everything which pulls him downwards, "anchoring [him] to the past and fatally undermining the joy of the present through a yearning for another time, another place, another state". 28

If there is a self which is sacrificed in Tarkovsky's The Sacrifice, it is Alexander's nihilist and world-weary self. This suggests that we should write the formalization of Alexander's sacrificial gesture as follows: Alexander (A) sacrificing his nihilist self (A') through sacrificing his house (B) to God (C) for the well-being of his family and friends (D).

\subsection{Was Alexander's Deed a Self-Sacrifice?}

Moliterno's characterization of Alexander as a prototypical nihilist is convincing. But does his Nietzschean reading of Tarkovsky's The Sacrifice not confirm Welz's reluctance to talk about self-sacrifice? In The Sacrifice, is it not "only a feature of the self or an aspect of its self-image that [is] sacrificed" (in other words, its nihilism and world-weariness), while "the sacrificing self itself survives the sacrifice of itself?". ${ }^{29}$ Does The Sacrifice not show, confirmed by Moliterno's interpretation, that, except in the case that someone is actually giving up his or her life for the other (which Alexander is clearly not doing), "the sacrificing self $[A]$ is irreducible to the sacrificed self $\left[A^{\prime}\right]$ " and "unable to get rid of itself?". ${ }^{30}$ And should we therefore not reserve the term 'selfsacrifice' for the rare and exceptional cases in which someone gives up their life for the other? ${ }^{31}$

\footnotetext{
27 Moliterno, "Zarathustra's Gift."

28 Moliterno, "Zarathustra's Gift."

29 Welz, "Love as Gift and Self-Sacrifice," 246.

30 Welz, "Love as Gift and Self-Sacrifice," 246.

31 Welz, "Love as Gift and Self-Sacrifice," 248.
} 
In my view, The Sacrifice offers a negative answer to these questions. This can be substantiated by Tarkovsky's own understanding of the gesture of Alexander's sacrificial gesture. In Sculpting in Time, the director explained that "Alexander (...) burns all the bridges behind him, leaving not a single path by which to return"32 and "breaks irrevocably with the world and with its laws", losing in this way his family and placing "himself outside all accepted norms". ${ }^{33}$ Put differently, Alexander cuts himself loose from the social fabric and becomes an outcast. And in this way he dies, not a biological death, but a "symbolic death", the death that consists in being separated from the symbolic order of language and community. ${ }^{34}$ That this kind of symbolic death is at stake in The Sacrifice is confirmed by the fact that Alexander's sacrifice precisely consists in giving up speech and the contact with his family (and his son in particular). What Alexander gives up is his symbolic self, his place in the symbolic order, his identity.

Thus, we can enlarge Welz's understanding of self-sacrifice and view Alexander's sacrificial gesture to be a self-sacrifice: We can speak of a selfsacrifice, not only when someone gives up their life for the sake of someone else but also when someone forsakes their symbolic self for something or someone. This leads us back to the second philosophical question that is raised by The Sacrifice, the question of the role played by sacrifice in the relationship of the sacrificing subject with the others.

\section{The Role of Alexander's Sacrificial Gesture in the Relation to} his Others

Although Moliterno's characterization of Alexander as a prototypical nihilist is convincing and has allowed us to interpret the sacrifice in The Sacrifice as a self-sacrifice, his interpretation of Alexander's sacrificial gesture is not without problems. Moliterno ignores the obvious religious context of that sacrifice, the fact that Alexander burns down his house as the outcome of a pact with God, and he also leaves aside the issue that this pact with God is made to save Alexander's beloved others (family, friends). For this reason, I will continue by taking a closer look at the role Alexander's sacrifice plays in the relationship

32 Tarkovsky, Sculpting in Time, 224.

33 Tarkovsky, Sculpting in Time, 227.

34 The distinction between "biological death" and "symbolic death" is adopted from the work of the Slovenian philosopher Slavoj Žižek, in whose work it is a recurrent theme. See, for instance, Slavoj Žižek, The Sublime Object of Ideology (London: Verso, 1989), 135. 
with his others and with God. In doing so, I make use of a section from an article of the Slovenian philosopher Slavoj Žižek, in which he distinguishes four ways sacrifice can play a role in a subject's relationship with the others and with God. ${ }^{35}$ I will discuss these four roles of sacrifice and examine to what extent each of them can be found in The Sacrifice.

\subsection{Dout des}

As noted by Žižek, the most elementary role sacrifice can play in the relationship with the other is that it serves to provoke a positive answer from that other: I give to the other something which is important to me, in order to get something back which is even more important to me (do ut des) ${ }^{36}$ If we formalize this, we get the following: A sacrificing $B$ to $C$ for the sake of $D$, where $\mathrm{D}=$ getting $\mathrm{B}$ ' from $\mathrm{C}$, while $\mathrm{B}$ ' is more important than B. Alexander's sacrifice can be interpreted as such a simple do ut des: To the other, in casu God, he offers things that are very dear to him - his house, the contact with his son - to obtain something even more important: The well-being of his family and friends.

In The Sacrifice, however, there seem to be deeper grounds than just, as Žižek puts it, "some profitable exchange". ${ }^{37}$ This is corroborated by the fact that Alexander, who is entering into a pact with God, had admitted earlier, in the first scene of the film, to having no relationship with God at all. ${ }^{38}$ Let us therefore take a look at what ultimately motivates Alexander's turn to God in the dark hour in which he and his beloved ones find themselves. If we turn to Alexander's prayer, we see that it culminates in his imploring to be released from the "deadly, sickening, animal fear" that he experiences in the face of the imminent nuclear holocaust. ${ }^{39}$ This fear is not merely the fear of death but of a far more terrifying fate. A nuclear war will not only result in Alexander's own death but in the death of most, if not all, human beings. Life on earth will be wiped out. Or, as Alexander puts it in his prayer:

35 Slavoj Žižek, "The Thing from Inner Space," in Sexuation (ed. Renata Salecl; Durham, NC: Duke University Press, 200o), 216-259 (243-247). See also Slavoj Žižek, On Belief(Thinking in Action; London: Routledge, 2001), 69-74.

36 Žižek, "The Thing from Inner Space," 243; Žižek, On Belief, 69.

37 Žižek, "The Thing from Inner Space," 243; Žižek, On Belief, 69.

38 Tarkovsky, Collected Screenplays, 517-518; The Sacrifice [film], 08:45-09:00.

39 Tarkovsky, The Sacrifice [film], o1:13:06-01:13:07. See also Tarkovsky, Collected Screenplays, 544: "sickening, deathly fear". 
[T] his war is the last, and terrible, and will leave neither victor nor vanquished; no towns, no villages, neither grass nor trees nor water in springs nor birds in the heavens. ${ }^{40}$

The death at stake here is not an individual's death, which has its place in the natural and symbolic order that consists in a succession of generations, but the complete destruction of that order, the total interruption of the succession of the generations. Or, to phrase it differently, the threat of a nuclear holocaust opens an abyss of nothingness, of the utter and complete meaninglessness and insignificance of everything that mattered for Alexander until now.

\section{2}

A Way to Restore Meaning

This leads us back to Žižek and the second role of sacrifice distinguished by him. According to Žižek, sacrifice can, beyond the profitable exchange of the do ut des, also serve as a way to restore meaning in the face of utter meaninglessness. Or, to put it in Žižek's own terms: Sacrifice is a way to convince ourselves that there is an Other (with capital $\mathrm{O}$ ) out there, the big Other who is pulling the strings and guarantees the good outcome of history. This means that we have the same formula, A sacrificing $B$ to $C$ for the sake of $D$, but with $\mathrm{D}=$ convincing A of C's existence. In this regard, Žižek speaks in an earlier book about "the trick of the sacrifice":

Sacrifice is a guarantee that the Other exists: That there is an Other who can be appeased by means of the sacrifice (...). [B]y the very act of sacrifice, we (presup)pose the existence of its addressee that guarantees the consistency and meaningfulness of our experience - so, even if the act fails in its proclaimed goal, this very failure can be read from within the logic of sacrifice as our failure to appease the Other. ${ }^{41}$

Even in the case that an act of sacrifice fails in its proclaimed goal, it still enables us to save the consistency and meaningfulness of our experience. Or, as Žižek explains:

Even if the Other does not grant my wish, I can at least be assured that there is another who - maybe - next time will respond differently: The

40 Tarkovsky, Collected Screenplays, 543; The Sacrifice [film], 01:11:57-01:12:22.

41 Slavoj Žižek, Enjoy Your Symptom! Jacques Lacan in Hollywood and Out (New York: Routledge, 1992), 64. 
world out there, inclusive of all catastrophes that may befall me, is not a meaningless piece of blind machinery, but a partner in a possible dialogue, so that even a catastrophic outcome is to be read as a meaningful response; we do not live in a kingdom of blind chance. ${ }^{42}$

It is clear that Alexander's sacrificial gesture can be interpreted as a way to assure the existence of the big Other. By approaching the universe as a dialogue partner, he is turning the course of events into a meaningful answer of the big Other: Even if the big Other would not respond as he would wish, he can still believe in the meaningfulness of what happens - for it is the result, not of some blind process, but of an agent that acts intentionally. Even if God, who occupies the place of the big Other for Alexander, would decide not to respond positively to Alexander's offer, his gesture would still enable him to save the meaningfulness of the world: The nuclear holocaust is no longer the outcome of blind and arbitrary processes, but wanted by God.

\subsection{Sacrifice for the Other}

However, it would be one-sided to say that Alexander is only interested in saving himself from the meaninglessness of the world. Before he promises God to give up everything he has, he prays for others, not only for his son, his wife and friends but also for humankind in general. ${ }^{43}$ This shows that Alexander's offer to God aims at saving others. This leads us to what Žižek has written on sacrifice for the other, the third type of sacrifice that he distinguishes. This third type of sacrifice can be formulated as follows: A sacrificing B for the sake of D, with $\mathrm{D}=$ saving the other. As can be derived from this formula, this kind of sacrifice does not (necessarily) have an addressee. Žižek finds an eminent example of such a sacrifice for the other in the Hollywood classic Beau Geste (1939) ${ }^{44}$ In this film, the eldest of three brothers, Michael Geste, steals his family's prize possession: An immensely expensive piece of jewellery. In doing so, he turns himself into an outcast, an ungrateful scoundrel. However, he did it to save his family, in particular his beloved aunt, from the shame of discovering that their prized jewel is actually a worthless replica. Or to express it once more within the formula: Michael (A) sacrificing his reputation (B) to save the reputation of his beloved family-others in the gaze of the big Other of society (D). ${ }^{45}$

\footnotetext{
42 Žižek, "The Thing from Inner Space," 243-44; Žižek, On Belief, 69.

43 See Tarkovsky, Collected Screenplays, 543; The Sacrifice [film], 01:10:40-01:11:57.

44 See http://www.imdb.com/title/ttoo31088/ for further details.

45 Žižek, "The Thing from Inner Space," 244; Žižek, On Belief, 70-71.
} 
If we compare the sacrifices of Michael from Beau Geste and Alexander from The Sacrifice, we find that in both cases somebody is becoming an outcast to save his family: Michael becomes a thief, Alexander a lunatic. In reference to the distinction between biological and symbolic death that was introduced above, we can say that both Michael and Alexander undergo a symbolic death. Michael is sacrificing his own reputation in order to conceal the truth for the big Other of society and to save his beloved family-others from shame and disgrace; Alexander engages in a bargain with the big Other, God, and promises to sacrifice his symbolic self because he wants to save his beloved others from an imminent nuclear holocaust.

\subsection{Sacrifice to Dupe the Other}

The example of Michael from Beau Geste shows that sacrifice can also serve to dupe the Other. In Beau Geste, Michael's sacrifice aims at letting the big Other, society, believe that his family possesses an expensive necklace, while in reality it possesses only a worthless replica. However, sacrifice can also be a means to make the Other believe that one does not yet possess some valuable and beloved object (A sacrificing $\mathrm{B}$ for the sake of $\mathrm{D}$ with $\mathrm{D}=$ duping the Other). This is the fourth role of sacrifice in the relationship to the Other that is distinguished by Žižek. To give an example of this, Žižek refers to a course of events returning in many Cold War spy films, such as Enigma from 1981:46 a secret agent is sent out on a mission which the agent's superiors intended to fail from the very start. The poor fellow had to be captured so that the Russians would believe that the CIA was still searching for what they actually already possessed (for instance, as in Enigma, some special computer chip enabling the CIA to decode the messages sent from the KG в headquarters to its outposts). Or, as Žižek explains:

The strategy here is to stage a search operation in order to convince the Other (the enemy) that one does not already possess what one is looking for - in short, one feigns a lack, a want, in order to conceal from the Other that one already possesses the agalma, the Other's innermost secret. ${ }^{47}$

More in general, the example of Enigma shows that sacrifice offers the subject a way to enjoy what is forbidden by the Law of the big Other. Žižek puts this as follows:

46 See http://www.imdb.com/title/ttoo83891/ for further details.

47 Žižek, “The Thing from Inner Space," 244-45. See also Žižek, On Belief, 71-72. 
Insofar as the Other of the symbolic Law prohibits jouissance [enjoyment], the only way for the subject to enjoy is to feign that he lacks the object that provides jouissance, that is, to conceal its possession from the Other's gaze by staging the spectacle of the desperate search for it. ${ }^{48}$

In this way, Žižek adds, the subject is able to escape from the pressure of the superego. The superego is, as noted by Dylan Evans, "the Other insofar as the Other commands the subject to enjoy". It is the dark underside of the Law and is nothing but the imperative to enjoy, ${ }^{49}$ that is, the implicit injunction to do precisely what is explicitly forbidden by the Law. This results in a guiltridden subject, torn between what is explicitly stated by the Law and the implicit command in the explicit prohibition to do the forbidden thing. Therefore, a sacrifice that aims at convincing the big Other that one does not yet possess the object of enjoyment is the ideal way to escape from this deadlock. ${ }^{50}$

This function of sacrifice, which can offer an individual a way to deal with the guilt that is caused by the enjoyment he experiences, can also be found in Tarkovsky's The Sacrifice. This is suggested by the prima facie strange reaction of Alexander when he hears the news that a nuclear war has broken out: "I've waited for this all my life... all my life was spent in expectation of this". ${ }^{51}$ This reaction is understandable in light of Alexander's long monologue at the beginning of the movie in which he, as we have seen above, expressed his desire for some action. Now, at last, something truly interruptive occurs and Alexander's deepest desire - what he was longing for at the outset of the film: Being freed, to put it in Moliterno's Nietzschean idiom, from the spirit of gravity that infects him - is about to be realized. Yet, this imminent realization of his desire (and the enjoyment that comes with it) conflicts with his symbolic existence as a father, a husband and a friend, and with the obligations connected to these roles. Therefore, that enjoyment is also a source of guilt, since, ultimately, Alexander enjoys the prospect of the death of his son, wife and friends as well as the total destruction of humankind. Alexander is trapped between the loyalties that are connected to his existence in the symbolic order and the enjoyment that comes with the prospect of an imminent end of the world. In this way, Alexander's sacrificial gesture can be understood as

\footnotetext{
48 Žižek, "The Thing from Inner Space," 246. See also Žižek, On Belief, 72.

49 Dylan Evans, An Introductory Dictionary of Lacanian Psychoanalysis (repr., London: Routledge, 1997), 201.

50 Žižek, "The Thing from Inner Space," 247; Žižek, On Belief, 74.

$5^{1} \quad$ Tarkovsky, Collected Screenplays, 538; The Sacrifice [film], o0:54:10-00:54:21.
} 
a compensation for the enjoyment he experiences: Through his self-sacrifice he can do something for his beloved others, paying off the guilt caused by enjoying the prospect of their destruction.

In the preceding pages, we have discussed Gino Moliterno's Nietzschean reading of Tarkovsky's The Sacrifice (with an eye to showing that Alexander's sacrificial gesture can be considered a self-sacrifice) as well as Slavoj Žižek's view on the role sacrifice can play in the relation of an individual with others and the big Other. At the end of this chapter, I want to examine what light Moliterno and Žižek shed on the third philosophical question that is raised by The Sacrifice: To what extent should we take Alexander as an exemplar? Is a sacrificial gesture like Alexander's advisable? Is it desirable? Should we all try to do like him?

In answering the question of the desirability of a sacrificial gesture like Alexander's, Moliterno and Žižek point in opposing directions. Moliterno's Nietzschean interpretation of The Sacrifice allows for a positive evaluation of Alexander's sacrificial gesture. As we have seen, Moliterno praises the sacrifice as "a joyful act of affirmative self-transfiguration" that enables Alexander to break free from the spirit of gravity, the burden of the past and his cultivation of world-weariness. Through a separation from language and community (or symbolic death), he receives an unprecedented freedom vis-à-vis the symbolic order. However, it is not clear how this symbolic death can be understood as 'joyful' and 'affirmative', and as an act of 'self-transfiguration' instead of selfdestruction (the destruction of the symbolic self), implied by our description of Alexander's sacrificial gesture in terms of symbolic death (a term I adopted from Žižek).

Moreover, as I have mentioned above, Moliterno ignores the obvious fact that Alexander's sacrifice was the outcome of a pact he made with God in order to save his family, friends and humankind at large from an imminent nuclear holocaust. And if we consider Alexander's sacrificial gesture in light of Žižek's discussion of the role sacrifice can play in the relationship between individuals with their others and with the big Other, that sacrifice appears in a completely different light. At least, this is the conclusion Žižek himself has drawn. Although he does not apply the four functions of sacrifice to the film, his discussion of these functions in the aforementioned article is framed by a twofold rejection of Alexander's sacrificial gesture. The section from which 
I have been quoting is titled "The Fake of the Sacrifice" and the question Žižek intends to answer here is what is wrong about the Tarkovskian sacrifice. ${ }^{52}$ After discussing the four roles, Žižek concludes that the problem posed in The Sacrifice is false and misleading. ${ }^{53}$

\subsection{A Disavowal of the True State of Affairs}

But what, then, is wrong about it? What exactly is false in it? Looking back at Žižek's four functions, we find that - once we move beyond profitable exchange - sacrifice in one way or another serves the aim of disavowing the true state of affairs. It is a means to conceal the truth: Either the truth that the big Other does not exist and therefore there is no ultimate guarantee of the meaningfulness of the universe, the truth that the beloved other is actually lacking and impotent, or the truth about my own lack. And this is, in Žižek's view, what is wrong with a sacrifice like Alexander's: It is, in the end, about sustaining illusions - the illusion of the other whose lack can be filled by what I have to offer, the illusion of the other that would be able to fill my lack, and the illusion of a big Other who guarantees the good outcome of the course of history.

According to Žižek, the fundamental problem with The Sacrifice is that its protagonist offers himself "as the instrument to deliver the big Other". The Sacrifice suggests that it is:

$[\mathrm{O}]$ nly by accomplishing an act which is totally senseless and 'irrational' that the subject can save the deeper global meaning of the universe as such. ${ }^{54}$

Or, to put it differently, what makes Alexander's sacrificial gesture false is that his:

$[\mathrm{R}]$ enunciation is functionalized in the service of the big Other, as the redemptive act destined to restore spiritual meaning to life. ${ }^{55}$

And this is why, according to Žižek, we should not follow Alexander's example, but resist the fatal attraction of sacrifice and accept that the big Other does

\footnotetext{
52 Žižek, "The Thing from Inner Space," 243.

53 Žižek, "The Thing from Inner Space," 247.

54 Žižek, "The Thing from Inner Space," 247.

55 Žižek, "The Thing from Inner Space," 247.
} 
not exist, while the lack of the other as well as our own lack are constitutive for what we are.

\subsection{Tarkovsky's Riddle-A Dual Interpretation Mode?}

Given the different evaluations of Alexander's sacrificial gesture offered by Moliterno and Žižek, what to conclude about the desirability of a self-sacrifice like Alexander's? What may account for the difference between Moliterno and Žižek is what they make of the fact that Alexander's act of sacrificing his symbolic self and disconnecting from the symbolic order does not disrupt or transform the established order. Whether this is considered problematic depends on one's perspective. From the perspective of someone who sacrifices their symbolic self, such a sacrifice may indeed be experienced as something positive because it enables, as we have seen, an unprecedented freedom from the burdens and constraints of existence in the symbolic order. This is the view defended by Moliterno. Yet, from the perspective of societal change, which is shared by Žižek, a self-sacrifice like Alexander's - which consists in a withdrawal from the symbolic order that does not affect that order as such can only be highly troubling. After all, it rather confirms than challenges the current status quo and therefore sustains the powers that be.

This of course raises the question which perspective is defended by Tarkovsky himself in his last film. If we can take Alexander to express Tarkovsky's personal view when he laments civilization as sinful (see above), there is a good reason to think that Tarkovsky would agree with the interpretation of Alexander's sacrifice in terms of symbolic death - which is confirmed by what the filmmaker wrote about Alexander's gesture in his book Sculpting in Time (see above). Yet, what distinguishes Tarkovsky from both Moliterno and Žižek is that he clearly understands Alexander's symbolic death in religious terms. In the aforementioned interview from 1986, Tarkovsky even spoke about the sacrifice of The Sacrifice in terms of redemption and spiritual rebirth: The movie is about "restor[ing] one's independence vis-à-vis the material things of life and consequently reaffirm[ing] one's spiritual essence" and "[Alexander] is a man who has understood that, to redeem himself, it has become indispensable to efface himself". ${ }^{56}$ Thus, according to Tarkovsky, Alexander is realizing his higher destiny through his sacrificial gesture. Žižek's atheism, in contrast, does not allow for this possibility. For him, there is no such higher destiny of humankind and any withdrawal from the world that does not disrupt the 
present order of things is false and misleading insofar as it contributes to the perpetuation of that order.

Ultimately, it is the presence or absence of God which decides about Alexander's sacrifice as desirable or false. If there is no God, any attempt to reach a higher destiny beyond this world is mistaken and Žižek is right to reject Alexander's sacrifice. But this very issue the film leaves unsolved. There are no clear signs in the film that there is indeed a God - although Tarkovsky believed there is. Therefore, Alexander's sacrifice remains ambiguous: In the end, it is not possible to decide whether he is a saint or a lunatic. 